\title{
Stimulus of Raw Oil Palm Trunk (OPT) Fibre on Durability Properties of Lightweight Foamed Concrete
}

\section{Md Azree Othuman Mydin}

To Link this Article: http://dx.doi.org/10.6007/IJARBSS/v12-i1/11925

DOI:10.6007/IJARBSS/v12-i1/11925

Received: 05 November 2021, Revised: 07 December 2021, Accepted: 24 December 2021

Published Online: 06 January 2022

In-Text Citation: (Mydin, 2022)

To Cite this Article: Mydin, M. A. O. (2022). Stimulus of Raw Oil Palm Trunk (OPT) Fibre on Durability Properties of Lightweight Foamed Concrete. International Journal of Academic Research in Business and Social Sciences, 12(1), 232-241.

\section{Copyright: (c) 2022 The Author(s)}

Published by Human Resource Management Academic Research Society (www.hrmars.com)

This article is published under the Creative Commons Attribution (CC BY 4.0) license. Anyone may reproduce, distribute, translate and create derivative works of this article (for both commercial and non0-commercial purposes), subject to full attribution to the original publication and authors. The full terms of this license may be seen at: http://creativecommons.org/licences/by/4.0/legalcode

\section{Vol. 12, No. 1, 2022, Pg. $232-241$}

Full Terms \& Conditions of access and use can be found at http://hrmars.com/index.php/pages/detail/publication-ethics 


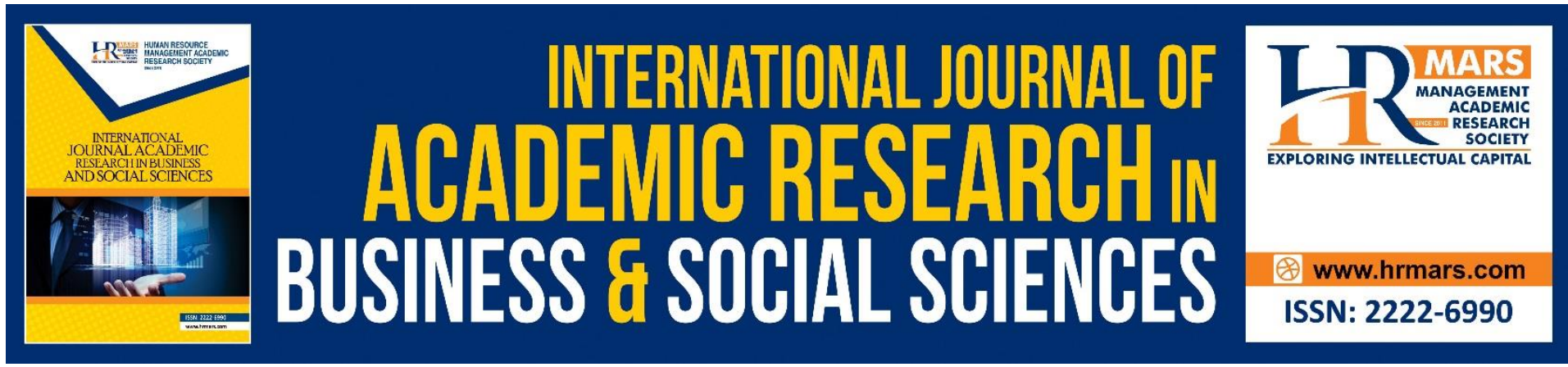

\title{
Stimulus of Raw Oil Palm Trunk (OPT) Fibre on Durability Properties of Lightweight Foamed Concrete
}

\author{
Md Azree Othuman Mydin \\ School of Housing, Building and Planning, Universiti Sains Malaysia, 11800, Penang, \\ MALAYSIA
}

Email: azree@usm.my

\begin{abstract}
Lightweight Foamed Concrete (LFC) has gained a huge amount of attention because of its high flowability, low self-weight, lower use of aggregate, low strength, and its thermal insulation. Furthermore, LFC is an environmentally friendly material because of its minimal usage of aggregate and high potential to incorporate waste material such as fibre. This research was conducted to assess the potential utilisation of oil palm trunk (OPT) fibre strengthened LFC in terms of its durability. Two densities of $600 \mathrm{~kg} / \mathrm{m}^{3}$ and $1200 \mathrm{~kg} / \mathrm{m}^{3}$, were cast and tested with 4 different percentages of OPT fibre, which were $0.15 \%, 0.30 \%, 0.45 \%$ and $0.60 \%$. The parameters evaluated were water absorption, porosity, drying shrinkage, ultrasonic pulse velocity. The results revealed that the inclusion of OPT in LFC helps to minimise water absorption and the porosity of LFC. Moreover, the inclusion of OPT also enhances the drying shrinkage and ultrasonic pulse velocity of LFC.
\end{abstract}

Keywords: Foamed Concrete, Porosity, Water Absorption, Drying Shrinkage, Ultrasonic Pulse Velocity

\section{Introduction}

LFC is a material low in mechanical properties compared to contemporary concrete of a normal weight (Serri et al., 2014). It can be defined as a cementitious material containing at least $20 \%$ by volume of mechanically trained moisture in the mortar slurry, in which air pores are fixed in the matrix utilising a suitable foam (Ramli et al., 2014). LFC can be created with the introduction of a foaming agent into a cement-based mortar. The foaming agent can be added, and the foam develops through a gentle yet rigorous mixing. Alternatively, the foaming agent can be aerated before it is applied to the mixture (Musa et al., 2019).

LFC has gained a huge amount of attention because of its high flowability, low selfweight, lower use of aggregate, low strength, and its thermal insulation. Moreover, LFC is an environmentally friendly material because of its minimal usage of aggregate and high potential to incorporate waste material such as fibre (Raj et al., 2019). The large amount of cement usage and the low elastic modulus of the aggregate in the production of LFC increases its drying shrinkage (Mydin et al., 2018). The addition of fibre into LFC is to strengthen its 
durability properties. Adding small volumetric fractions of short fibres can reduce the impact of early-age reduction of the concrete's durability. It also can restrict the growth of cracks under loads.

There has been a broad utilization of natural fibres in producing LFC due to the increasing interest in natural fibres in clinging to a more environmental and cost-effective value in construction industries. However, it should be understood from a structural standpoint that the primary purpose of adding fibre in cementitious material is to improve the durability of engineering properties. Natural fibre can play an important role to enhance the matrix bond that will help to develop the tensile strength and structural integrity of the concrete. Momen et al (2018) determined that the finest fibres have a very good essence that assist to improve the qualities of concrete. The study also stated that the use of natural fibre can help to improve the shrinkage and ductility. Reinforced concrete with the inclusions of fibres can reduce plastic shrinkage and improve durability, which is in line with the study conducted by Jalal et al (2017) which postulated that the flexural resistance and durability of concrete will be improved by including the fibres into the concrete.

Thus, natural fibre is seen as a resolution to improve LFC with improved durability performances, which is a new form of binder that can combine Portland cement in bonding with cement matrices. The fibres are mostly sporadic, erratically dispersed throughout the cement matrices (Elrahman et al., 2019). The inclusion of fibres in FC is to delay and control the tensile cracking of composite material (Munir et al., 2015). Fibres thus transform the inherent unstable tensile crack propagation to slow controlled crack growth. This crack controlling properties of the fibre helped to reinforce the delays and the initiation of flexural and shear cracking (Memon et al., 2018). It imparts extensive post cracking behaviour and extensively enhances the ductility of the composite (Jhatial et al., 2017). Therefore, this research explores the potential utilisation of OPT fibre in FC to improve the durability properties of LFC.

\section{Material Constituents}

The Ordinary Portland cement (OPC) was used in this study, complying with the BS 12 standard. This product is available in $50 \mathrm{~kg}$ bags and in bulk. Fine inorganic material forms a paste once water is added to the mixture. Next, the fine aggregate used in this study was natural fine sand supplied by a local distributor. Sieve analysis was conducted to assess the suitability of the sand to use according to BS882. Fine sand was used with a size of $1.18 \mathrm{~mm}$ to improve the LFC flow attributes and stability. Additionally, protein agent used for this study was Noraite-PA-1, at a ratio of 1:33 to the volume of water. The clean water used in the mix together with the protein agent was to create a good foaming agent. The density of FC was determined by the volume of foam added into the mix. The stability of foam is important in producing FC since the generator will act as a medium to transfer the agent into the stable foam. The weight of the foam used in this investigation varied between $60-80 \mathrm{~g} /$ litre. Finally, the oil palm trunk (OPT) fibre utilized in this study was washed properly before being used as an infill in LFC. The fibre volume used was $0.15 \%, 0.30 \%, 0.45 \%, 0.60 \%$ and $0.00 \%$ of the total weight mix volume. A total of 5 mixes were prepared for this research. For all 5 mixes, the sand-cement ratio was fixed at 1:1.5, and the water-cement ratio was 0.4 . 


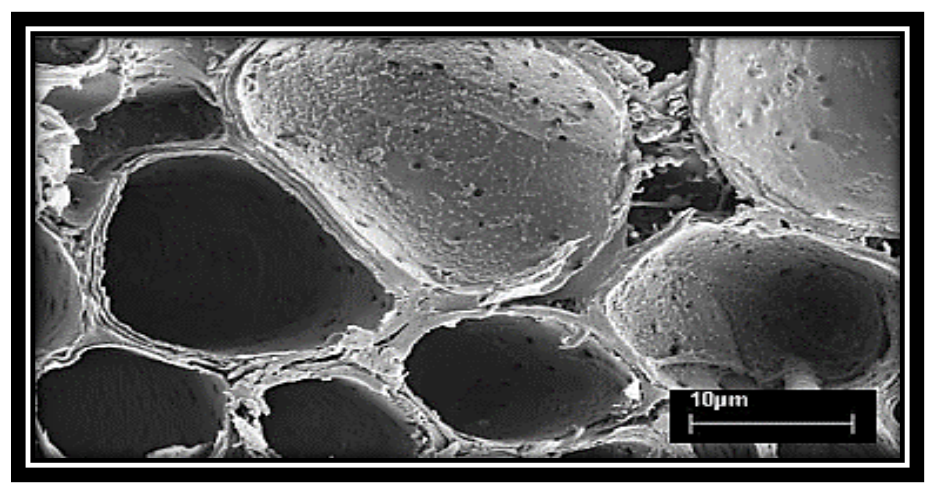

Fig. 1 - Morphology details of oil palm trunk (OPT) fibre structures

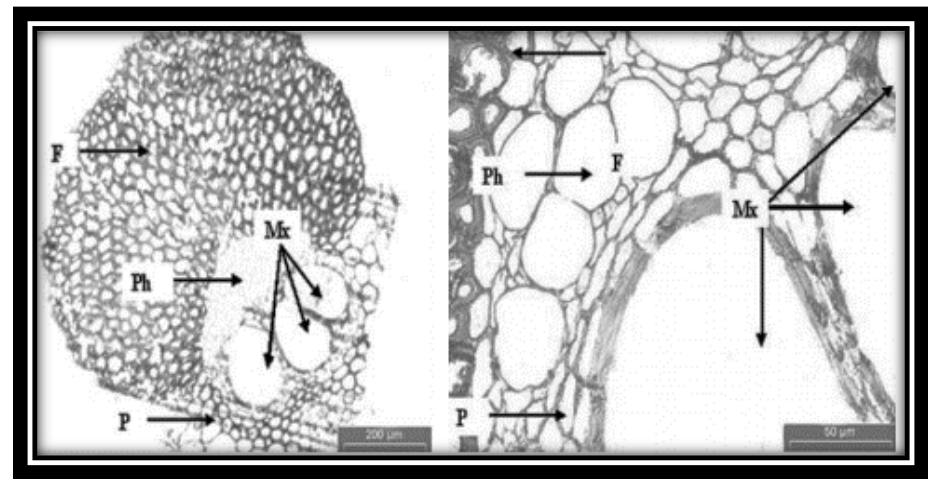

Fig. 2 - Transverse section of oil palm trunk fibre

\section{Experimental Setup}

The water absorption test was conducted on a $75 \mathrm{~mm}$ diameter $\times 100 \mathrm{~mm}$ height cylinder according to BS 1881: Part 122 (BS1881-122, 1983) (see Fig. 3), and the porosity test was conducted according to BS 1881: Part 122 (BS1881-122, 1983) on a $45 \mathrm{~mm}$ diameter $\times 50 \mathrm{~mm}$ height cylinder (see Fig. 4). The drying shrinkage test was performed on a $5 \mathrm{~mm} \times 75 \mathrm{~mm} x$ $275 \mathrm{~mm}$ prism according to ASTM C878 (ASTM C878, 2014) (see Fig. 5), and the ultrasonic pulse velocity (UPV) test was performed on a $100 \mathrm{~mm} \times 100 \mathrm{~mm} \times 500 \mathrm{~mm}$ prism according to BS 12504: Part 4 (BS12504-4, 2004)

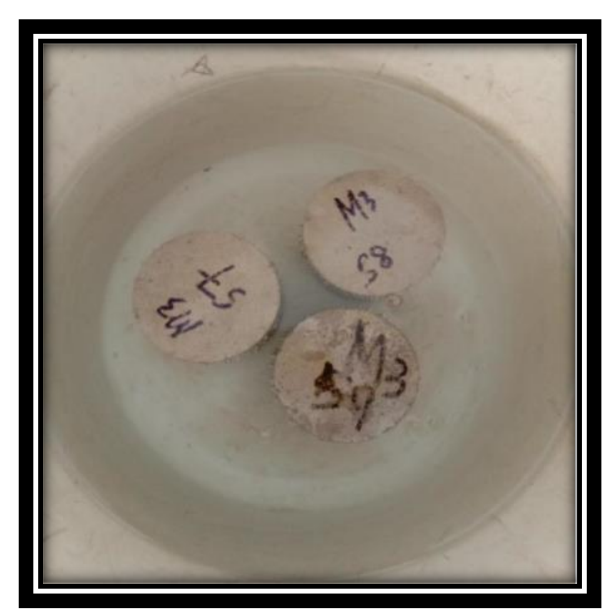

Fig. 3 - Water absorption test was performed according to BS 1881: Part 122 


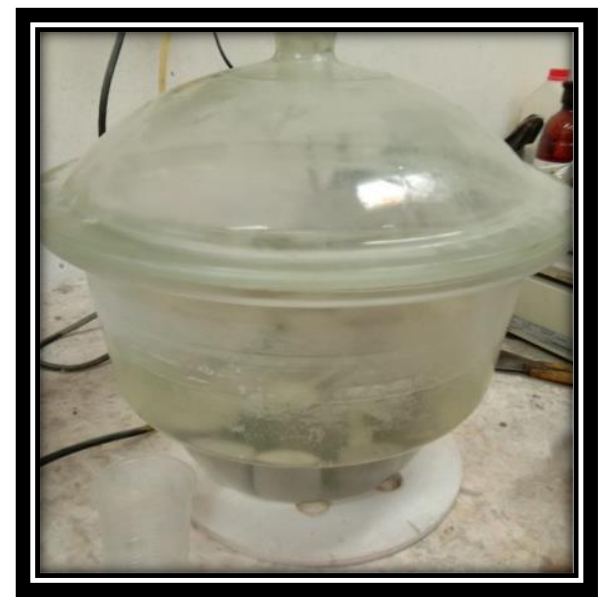

Fig. 4 - Porosity test was performed according to BS 1881: Part 122

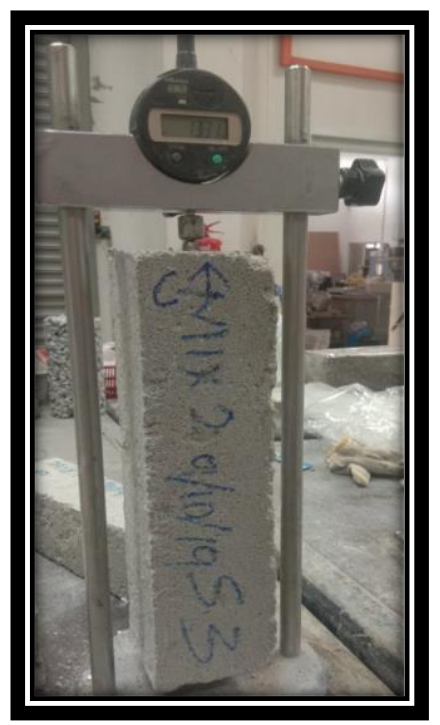

Fig. 5 - Shrinkage test was carried out according to ASTM: C 878

\section{Results and Discussion}

\section{Water Absorption}

Fig. 6 shows that the increase of OPT fibre will reduce the water absorption in the specimen of lightweight FC. The OPT fibre at $0.15 \%$ absorbs water higher compared to other OPT percentages, namely $21.9 \%$ for $600 \mathrm{~kg} / \mathrm{m}^{3}$ and $11.0 \%$ for $1200 \mathrm{~kg} / \mathrm{m}^{3}$. This is because the small pore size and volume will prevent water from infiltrating the specimen. The control specimens were $22.6 \%$ for $600 \mathrm{~kg} / \mathrm{m}^{3}$ and $12.1 \%$ for $1200 \mathrm{~kg} / \mathrm{m}^{3}$, which showed the highest result since it absorbs water. For the $0.30 \%$ of OPT it shows $19.9 \%$ for $600 \mathrm{~kg} / \mathrm{m}^{3}$ and $9.8 \%$ for $1200 \mathrm{~kg} / \mathrm{m}^{3}$, and for $0.45 \%$ of OPT it shows $19.3 \%$ for $600 \mathrm{~kg} / \mathrm{m}^{3}$ and $9.3 \%$ for $1200 \mathrm{~kg} / \mathrm{m}^{3}$. Lastly, for $0.60 \%$ of OPT it shows $18.1 \%$ for $600 \mathrm{~kg} / \mathrm{m}^{3}$ and $8.8 \%$ for $1200 \mathrm{~kg} / \mathrm{m}^{3}$. An increment of OPT percentages will reduce the water absorption of FC. 


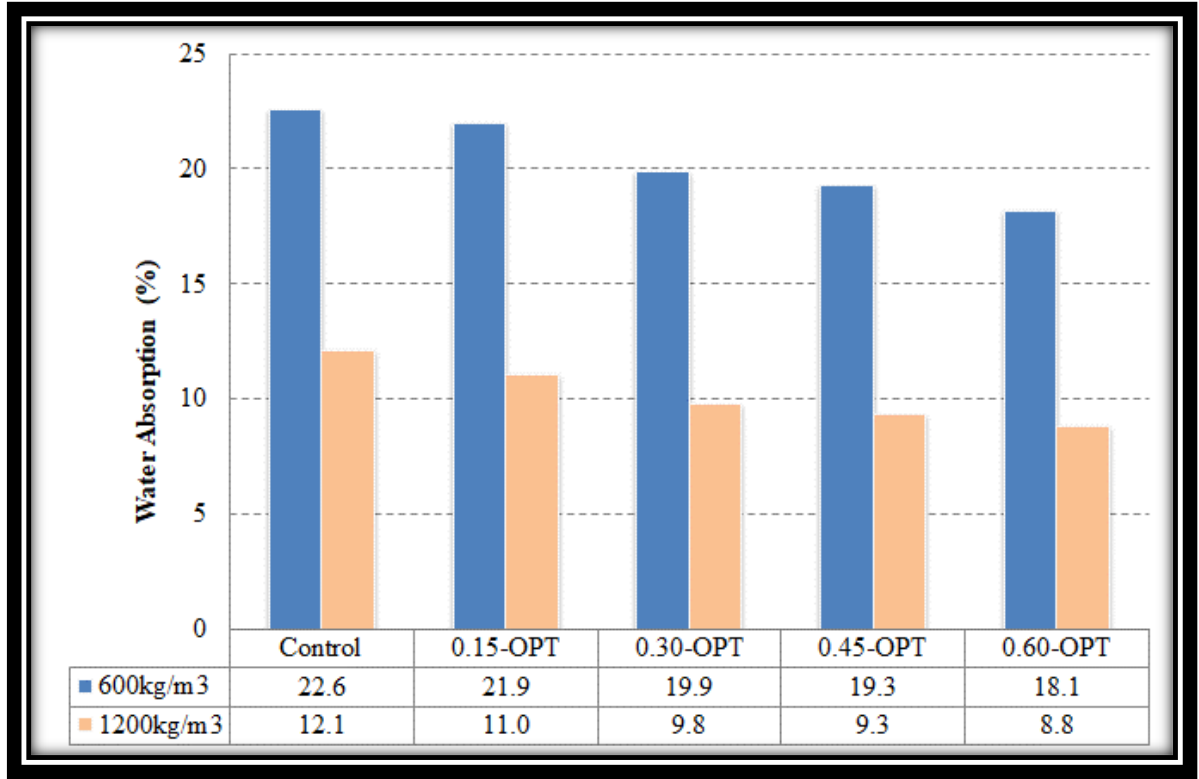

Fig. 6 - The water absorption capacity of FC with different percentages of OPT fibre of both densities

\section{Porosity}

Fig. 7 shows the porosity result for $600 \mathrm{~kg} / \mathrm{m}^{3}$ and $1200 \mathrm{~kg} / \mathrm{m}^{3}$ densities of FC with different percentages of OPT fibre. The OPT fibre at $0.15 \%$ absorbs water higher compared to other percentages of OPT; $67.8 \%$ for $600 \mathrm{~kg} / \mathrm{m}^{3}$ and $33.6 \%$ for $1200 \mathrm{~kg} / \mathrm{m}^{3}$. The result shows that the increase of OPT will decrease porosity. This is because the small pore size and volume will prevent water from infiltrating the specimen. The control specimen was $69.7 \%$ for $600 \mathrm{~kg} / \mathrm{m}^{3}$ and $35.5 \%$ for $1200 \mathrm{~kg} / \mathrm{m}^{3}$, which shows the highest result since it absorbs water. Next, for the $0.30 \%$ of OPT it shows $66.9 \%$ for $600 \mathrm{~kg} / \mathrm{m}^{3}$ and $32.2 \%$ for $1200 \mathrm{~kg} / \mathrm{m}^{3}$. In addition, for $0.45 \%$ of OPT it shows $65.7 \%$ for $600 \mathrm{~kg} / \mathrm{m}^{3}$ and $31.7 \%$ for $1200 \mathrm{~kg} / \mathrm{m}^{3}$. Lastly, for $0.60 \%$ of OPT it shows $64.8 \%$ for $600 \mathrm{~kg} / \mathrm{m}^{3}$ and $30.6 \%$ for $1200 \mathrm{~kg} / \mathrm{m}^{3}$. The result in this experiment shows that the increment of OPT percentages reduces the porosity of FC.

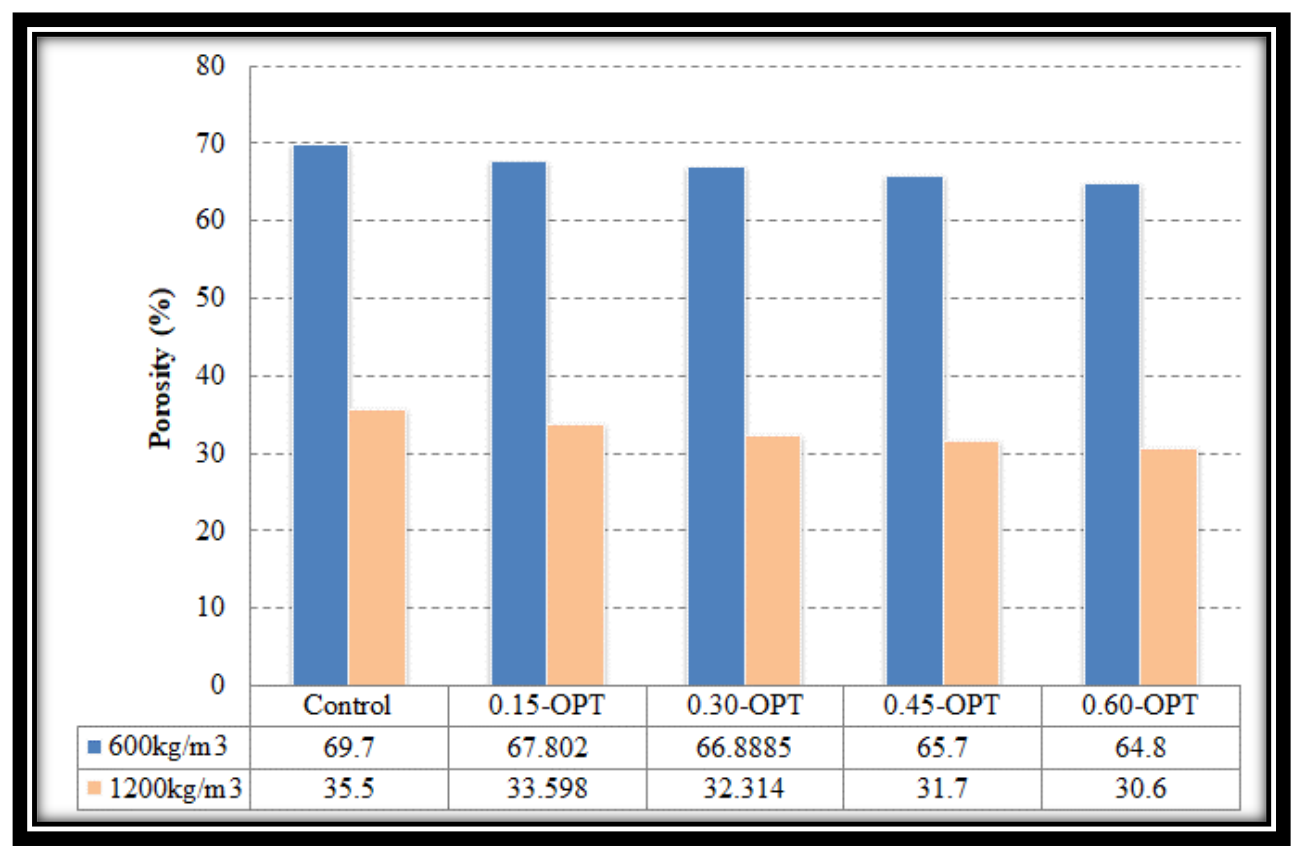

Fig. 7 - The porosity of FC with different percentages of OPT fibre of both densities 


\section{Drying Shrinkage}

Figures 8 and 9 show that drying shrinkage for all specimens are high from an early age until 30 days and then continues to increase. The addition of OPT causes the drying shrinkage of the specimen to increase. The $0.45 \%$ OPT fibre leads to a better result of drying shrinkage for both densities because it drastically increases. The density of $600 \mathrm{~kg} / \mathrm{m}^{3}$ causes more general shrinkage than $1200 \mathrm{~kg} / \mathrm{m}^{3}$, given the higher amount of foam content used in the mix. OPT reacts as an aggregate that gives the compact composition of the microstructure, which lessens and decreases the size and measures of the pores, thus improving the drying shrinkage (Fu et al., 2020). The highest value is for the control specimen. Notably, the highest value of drying shrinkage is not good for concrete since it can cause cracks in the future.

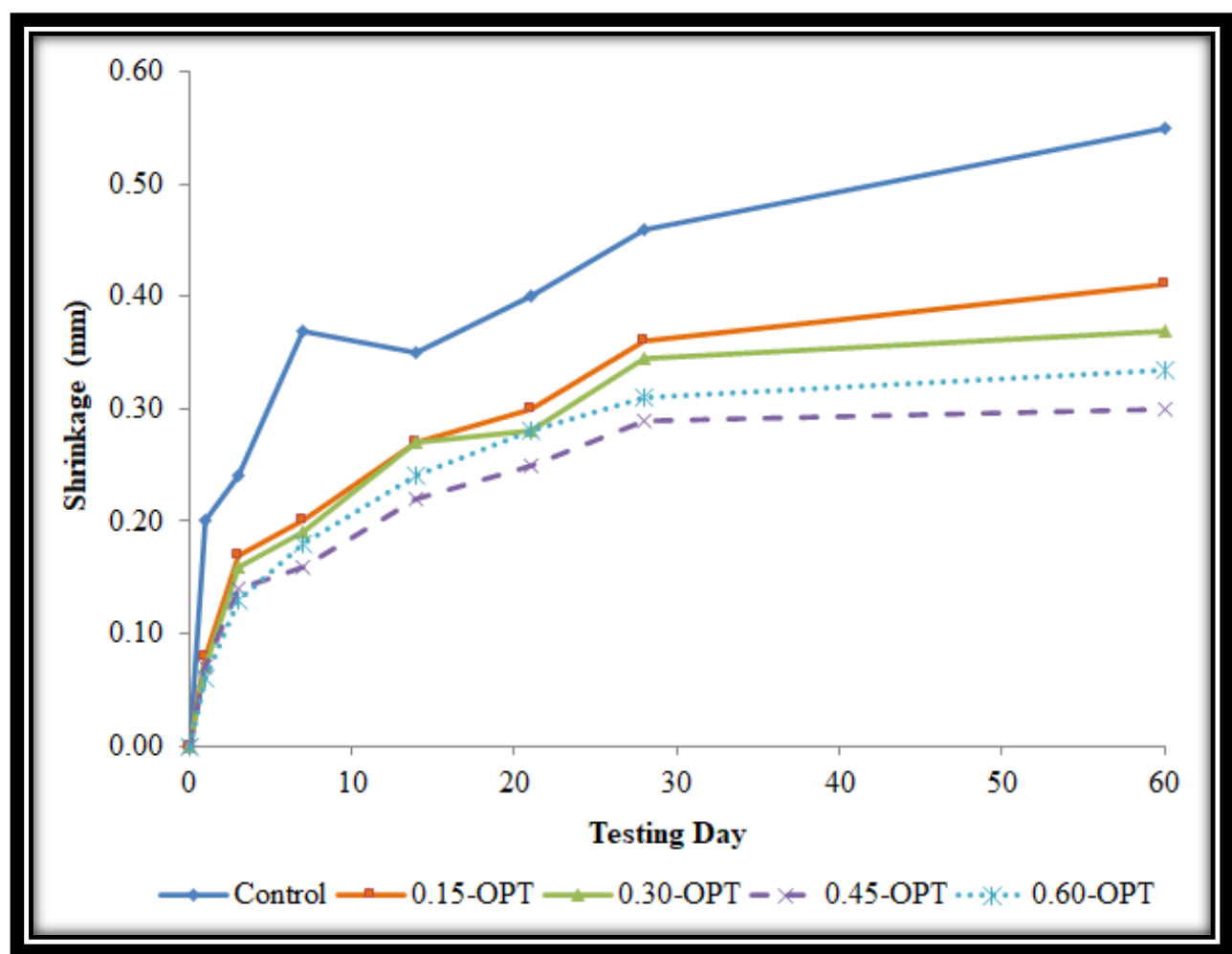

Fig. 8 - Drying shrinkage result with different percentage of OPT fibre for $600 \mathrm{~kg} / \mathrm{m}^{3}$ density 


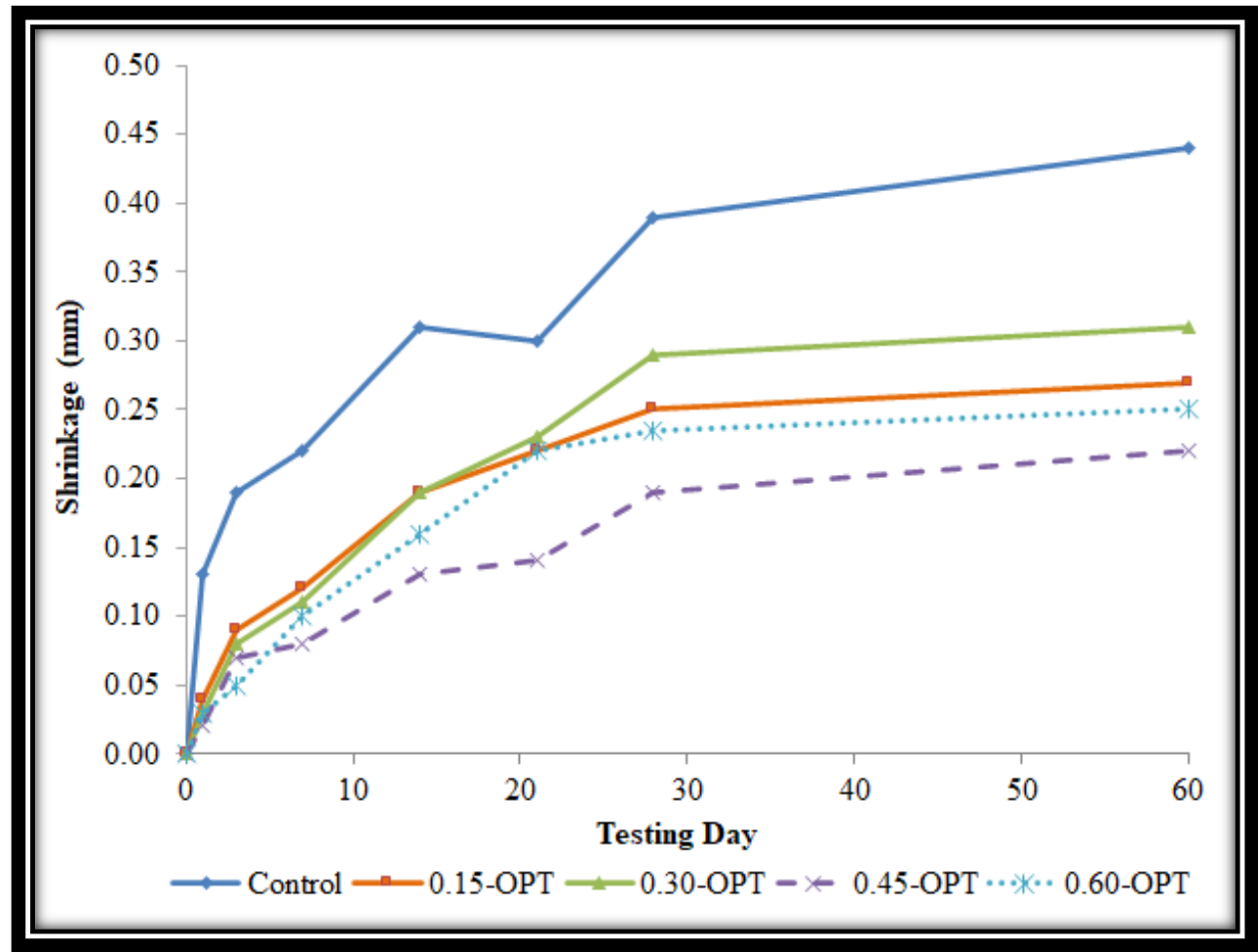

Fig. 9 - Drying shrinkage result with different percentage of OPT fibre for $1200 \mathrm{~kg} / \mathrm{m}^{3}$ density

\section{Ultrasonic Pulse Velocity (UPV)}

Fig. 10 shows the UPV result of $600 \mathrm{~kg} / \mathrm{m}^{3}$ and $1200 \mathrm{~kg} / \mathrm{m}^{3}$ densities of FC with different percentages of OPT fibre. The UPV method is completely harmless and is suitable for assessing the quality of concrete. This method can be used to detect internal cracks and other defects and concrete changes such as deterioration in an aggressive chemical environment, freezing and dilution. From the graph below, we can conclude that the concrete does not contain large voids or cracks, which would no doubt affect its structural integrity. The $0.45 \%$ OPF volume fraction contributed to the highest result of UPV. Therefore, the UPV is important to assess the presence of large voids in the interface zone and, finally, to check the OPT's quality and strength. The lowest value of UPV was for the control specimen. This method allows for calculating the strength of concrete and for concrete test specimens. 


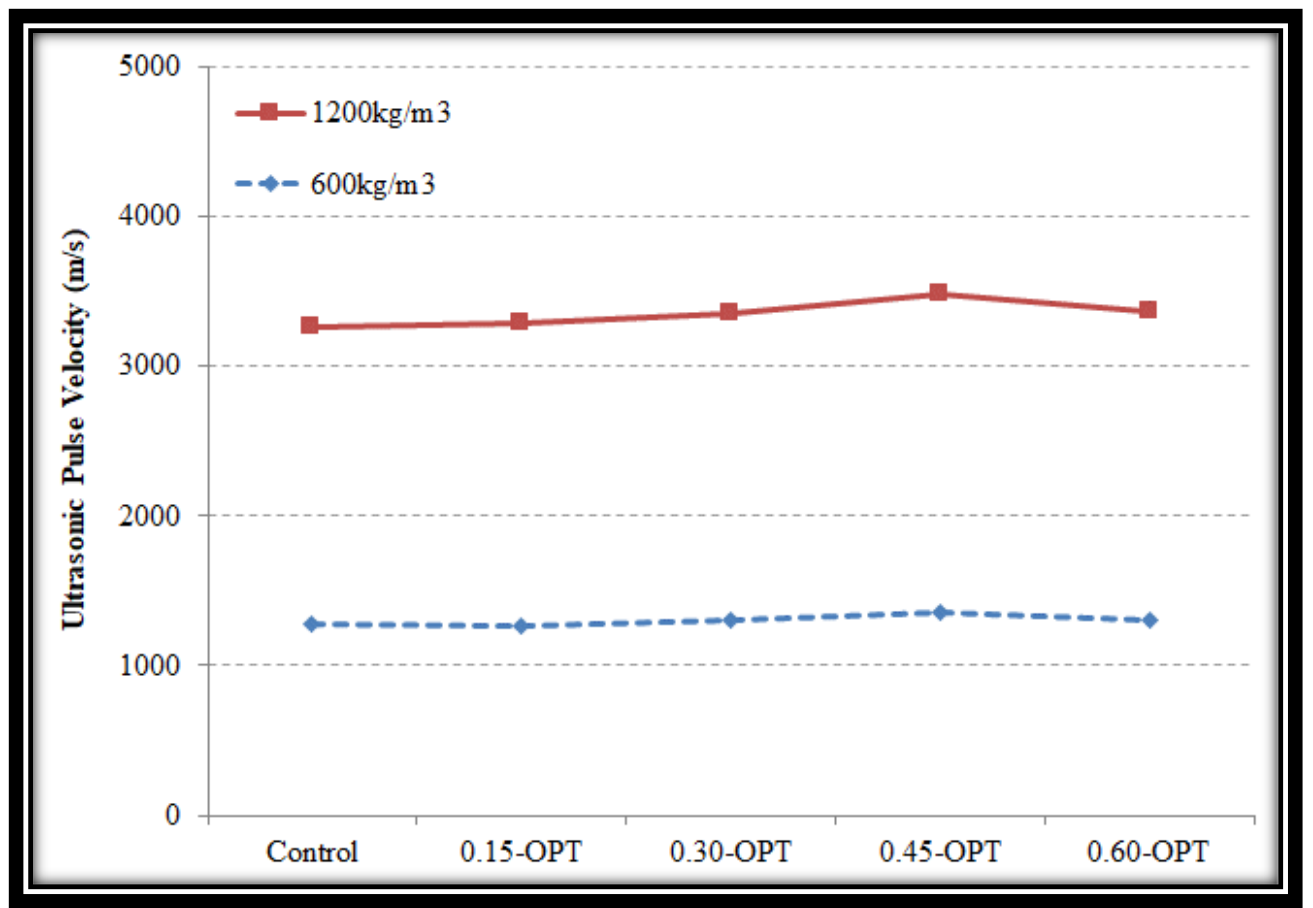

Fig. 10 - Ultrasonic pulse velocity (UPV) of FC with different percentages of OPT fibre of both densities

\section{Conclusion}

For this research, the durability properties of LFC with the inclusion of different proportions of oil palm trunk (OPT) fibre into different densities of LFC were carried out. Two densities of LFC, $600 \mathrm{~kg} / \mathrm{m}^{3}$ and $1200 \mathrm{~kg} / \mathrm{m}^{3}$, were prepared and tested with five different percentages of OPMF added, which were $0.00 \%, 0.15 \%, 0.30 \%, 0.45 \%$ and $0.60 \%$. The experimental results reveal that the best results, in terms of the durability properties (water absorption, porosity, drying shrinkage and ultrasonic pulse velocity), were achieved with the optimum inclusion of $0.45 \%$ volume fraction of OPT fibre for both densities considered in this research. At $0.45 \%$ volume fraction of OPT fibre, the fibres and the cementitious matrix attained maximum compaction, which resulted in good mix homogeneity. Beyond the optimum level of OPT fibre addition, agglomeration and the non-uniform dispersion of fibres was observed, which led to decrease in all durability properties. The theoretical and contextual contribution of this research will pave the way to fabricate high performance LFC with excellent durability properties with the addition of oil palm biomass waste specifically trunk fibre. The output from this experimental investigation will give a better insight of the potential use of natural fibre in LFC.

\section{References}

ASTM C878 / C878M-14a. (2014). Standard Test Method for Restrained Expansion of Shrinkage-Compensating Concrete, ASTM International, West Conshohocken, PA

BS 12504-4. (2004). Testing concrete. Determination of ultrasonic pulse velocity. British Standard Institution: 1-18

BS 1881-122. (1983). Testing concrete. Method for determination of water absorption. British Standards Institution: 1-14 
Elrahman, M. A., El Madawy, M. E., Chung, S. Y., Sikora, P., Stephan, D. (2019). Preparation and characterization of ultra-lightweight foamed concrete incorporating lightweight aggregates. Applied Sciences (Switzerland), 9(7): 1-12

Fu, Y., Wang, X., Wang, L., Li, Y. (2020). Foam Concrete: A State-of-the-Art and State-of-theart Practice Review. Advances in Materials Science and Engineering, 6153602, 1-25

Jalal, M. D., Tanveer, A., Jagdeesh, K., Ahmed, F. (2017). Foam concrete. International Journal of Civil Engineering Research, 8(1): 1-14 Hedjazi S. (2019). Compressive Strength of Lightweight Concrete. In Intech Open:1-18

Jhatial, A. A., G. W. Inn, N. Mohamad, U. J., Alengaram, K. H., Mo, R. A. (2017). Influence of polypropylene fibres on the tensile strength and thermal properties of various densities of foamed concrete. IOP Conference Series: Materials Science and Engineering 271 (1), 012058

Memon I. A., Jhatial, A. A., Sohu S., Lakhiar M. T., Hussain Z. (2018). Influence of Fibre Length on the Behaviour of Polypropylene Fibre Reinforced Cement Concrete. Civil Engineering Journal, 4(9): 2124-2131.

Munir, A., Abdullah, Huzaim, Sofyan, Irfandi, \& Safwan. (2015). Utilization of palm oil fuel ash (POFA) in producing lightweight foamed concrete for non-structural building material. Procedia Engineering, 125, 739-746.

Musa, M., Othuman, M. M. A., Abdul Ghani, A. N. (2019). Thermal properties of foamed concrete with addition of empty fruit bunch (EFB) fiber. International Journal of Innovative Technology and Exploring Engineering. 8(10):4662-4670

Mydin, M. A. O., Zamzani, N. M., Ghani, A. N. A. (2018). Effect of alkali-activated sodium hydroxide treatment of coconut fibre on mechanical properties of lightweight foamed concrete, in 3rd International Conference on Applied Science and Technology. 5055512:020108.

Raj, A., Sathyan, D., Mini, K. M. (2019). Physical and functional characteristics of foam concrete: A review. Construction and Building Materials. 221:787-799.

Ramli, M., Kwan, W. H., Abas, N. F. (2013). Strength and durability of coconut-fibre-reinforced concrete in aggressive environments. Construction and Building Materials. 38:554-566.

Serri, E., Suleiman, M. Z., Mydin, M. A. O. (2014). The effects of oil palm shell aggregate shape on the thermal properties and density of concrete. Advanced Materials Research. 935:172-175 